\title{
Analisis Perbandingan Kinerja Keuangan Bank Syariah Mandiri Dengan Bank Mandiri Konvensional
}

\author{
Asraf \\ Sekolah Tinggi Ekonomi (STIE) Pasaman \\ Email: asrafyappas@gmail.com \\ Yurasti \\ Sekolah Tinggi Ekonomi (STIE) Pasaman \\ Suwarni \\ Sekolah Tinggi Ekonomi (STIE) Pasaman
}

\begin{abstract}
Islamic banking which has operated in Indonesia for 28 years, was able to gain a market share of only $5.94 \%$. This study analyzes aspects of the weaknesses of Islamic banks, traced from their financial performance. The study was conducted by comparing the financial ratios of Bank Syariah Mandiri (BSM) with Bank Mandiri where both banks operate with different systems and are in one business group. The results showed the weak point of BSM compared to Bank Mandiri was the low quality of productive assets which impacted on the low profitability. In addition, the cost efficiency of BSM is also lower, which is shown by the higher BOPO even though the NOM / NIM of the two banks is relatively the same. This weakness also makes BSM's ability to produce internal funding sources also low. The results of this study recommend that Islamic banks be able to compete and gain profit from sharia business opportunities, by maximizing credit management, increasing efficiency and developing fee-based income-based products.

Keywords: CAR, NPL, ROA, ROE, BOPO, LDR
\end{abstract}

\section{Abstrak}

Bank sistem syariah yang sudah beroperasi di Indonesia selama 28 tahun ternyata hanya mampu meraih pangsa pasar 5,94\% saja. Penelitian ini menganalisis aspek yang menjadi kelemahan bank syariah ditelusuri dari kinerja keuangannya. Penelitian dilakukan dengan memperbandingkan ratio keuangan Bank Syariah Mandiri (BSM) dengan Bank Mandiri dimana kedua bank ini beroperasi dengan sistem yang berbeda dan berada dalam satu grup usaha. Hasil penelitian menunjukkan titik lemah BSM dibandingkan dengan Bank Mandiri adalah pada rendahnya kualitas aktiva produktif yang berimbas pada rendahnya profitabilitas. Selain itu, efisiensi biaya BSM juga lebih rendah yang ditunjukkan oleh BOPO yang lebih tinggi meskipun NOM/NIM kedua bank relatif sama. Kelemahan ini sekaligus membuat kemampuan BSM dalam menghasilkan sumber dana internal juga rendah. Hasil penelitian ini merekomendasikan bahwa agar perbankan syariah mampu bersaing dan meraih keuantungan dari peluang bisnis syariah, adalah dengan memaksimalkan manajemen kredit, meningkatkan efisiensi dan mengembangkan produk produk berbasis fee based income.

Kata kunci: CAR, NPL, ROA, ROE, BOPO, LDR

\section{Pendahuluan}

Bank adalah Lembaga Keuangan yang kegiatannya menghimpun dana dari masyarakat dan menyalurkan kembali kepada masyarakat yang membutuhkan serta memberikan jasa bank lainya (Kasmir, 2012). Bank berperan sangat penting dalam aktivitas perekonomian baik nasional mauun internasional. Selain peran strategis itu, bank juga bisnis yang menarik minat investor.

Karena bisnis perbankan melibatkan dana dan resiko yang besar, maka di Indonesia pada awalnya diterapkan aturan yang ketat sehingga bisnis ini didominasi oleh bank-bank milik Pemerintah. Namun di era 1980-an Pemerintah melakukan deregulasi perbankan yang membuka peluang bagi swasta untuk terlibat lebih jauh pada bisnis ini. Bukan saja perluasan dari aspek kepemilikan 
yang dibuka, akan tetapi juga dari system operasi. Bila semula hanya ada satu jenis sistem operasional perbankan, maka lahir pula sistem Syariah yang berbeda dengan sistem perbankan konvensiol yang dikenal selama ini. Sejak saat itu pasang surut bisnis perbankan dimulai. Implikasi dari kebijakan deregulasi itu mendorong lahirnya sejumlah bank swasta yang tumbuh bak jamur di musim hujan. Produk-produk perbankan jorjoran ditawarkan dengan berbagai daya tariknya. Persaingan bisnis perbankan sangatlah tinggi. Produk dana ditawarkan dengan bunga yang tinggi dengan iming-iming hadiah yang menggiurkan sementara produk kredit ditawarkan dengan syarat yang mudah. Perbankan dengan sistem Syariah juga tidak mau ketinggalan dalam memanfaatkan moment itu. Selain terdapat dorongan dari sebagian masyarakat Muslim, sejumlah praktisi perbankan membangun asumsi dari fakta bahwa masyarakat Indonesia mayoritas Muslim dan tingkat religiusitas yang relatif baik maka diyakini bisnis perbankan sistem syariah memiliki prospek yang baik.

Dalam era persaingan perbankan itu semua bank berlomba mendapatkan simpati dari masyarakat. Bank sistem Syariah menggunakan jurus sesuai dengan spesifik yang dimilikinya. Dalam beberapa tahun kemuadian terjadi peningkatan yang signifikan portfolio kredit perbankan dan jumlah uang beredar. Apa yang terjadi kemudian adalah terjadi over heating ekonomi nasional. Ujung dari ini semua maka terjadilah krisis moneter diakhir tahun 1990-an yang berlanjut pada krisis multi dimensi yang hebat. Sejumlah bank rontok tak terkecuali bank-bank milik Pemerintah. Kran yang terlalu besar dibuka melalui kebijakan deregulasi sebelumnya, mulai ditata kembali. Pemerintah mengambil alih kendali penataan sistem perbankan nasional dengan membentuk lembaga BPPN yang bertugas membenahi carut marut kondisi perbankan saat itu. Bank-bank yang mengalami masalah ditangani sesuai tingkat permasalahan yang dialami. Ada yang langsung ditutup, dan ada juga yang dimerger. Diantara bank yang dimerger terdapat 4 buah bank milik Pemerintah yaitu Bank Exim, Bank Dagang Indonesia, Bank Bhumi Daya dan Bapindo yang dilebur menjadi sebuah bank yang diberi nama Bank Mandiri.

Satu hal yang menjadi cacatan adalah berlanjutnya kompetisi bisnis baik antara bank-bank milik Pemerintah dengan bank-bank milik Swasta, maupun antara bank sistem konvensional dengan bank sistem syariah. Dalam memanfaatkan peluang pasar, Bank Mandiri juga mendirikan anak perusahaan yang bergerak pada bisnis bank dengan sistem syariah yaitu Bank Syariah Mandiri (BSM). Sejak saat itu grup Bank Mandiri memiliki dua buah bank yaitu BSM dan Bank Mandiri yang beroperasi secara konvensional. Penelitian ini akan menganalisis bagaimana kinerja bisnis dua bank dengan sistem berbeda yang berada didalam satu grup setelah hampir dua dekade menjalankan usahanya yaitu BSM dan Bank Mandiri. Penelitian ini menggunakan pendekatan kamparasi dari kinerja keuangan masing-masing. Parameter kinerja keuangan dibatasi pada ratio ratio keuangan yang digunakan Otoritas Jasa Keuangan (OJK) dalam menilai kesehatan Bank Umum.

\section{Literature Review}

\subsection{Bank Syariah VS Bank Konvensional}

Bank syariah adalah bank yang beroperasi sesuai dengan prinsip Syariat Islam. Kalau dalam bisnis finansial yang dikelola bank konvensional menerapkan sistem bunga, maka dalam syariat Islam itu tidak diperkenankan karena termasuk riba. Syariat Islam mengharamkan riba dan menghalalkan jual beli. Allah menghalalkan jual beli dan mengharamkan riba (QS Al-Baqoroh ayat 279). Oleh karena itu bank syariah menyandarkan akad kreditnya dengan objek jual beli, sewa, kerjasama bisnis dan lain-lain yang diperbolehan dalam syariat Islam. Dalam jual beli syariah Islam memperbolehkan mengambil keuntungan, sedangkan dalam sewa menyewa diperbolehkan ada biaya sewa, sementara dalam kerjasama bisnis ada sistem bagi hasil. Prinsipprinsip inilah yang mendasari objek bisnis bank syariah sehingga bisnis keuangan dalam bank syariah tidak mungkin berdiri sendiri, akan tetapi merupakan bagian dari paket transaksi jual beli, 
sewa, kerjasama bisnis dan lain-lain. Secara prinsip hal ini sangat berbeda dengan sistem bank konvensional dimana objek utamanya adalah pinjam meminjam uang dimana si peminjam diharuskan membayar lebih dari hutangnya. Adapun dalan aktivitas analisa kredit bank konvensional juga membahas objek pembiayaan, maka ini lebih pada keperluan analisa kredit untuk meminimalisir resiko kredit yaitu menghinadri unpaid.

Dalam perspektif perundang-undangan maka bank syarian menurut Undang-Undang No. 21 Tahun 2008 adalah bank yang dalam aktivitasnya, baik penghimpunan dana maupun dalam rangka penyaluran dananya memberikan dan mengenakan imbalan atas dasar prinsip syariah yaitu jual beli dan bagi hasil. Sedangkam menurut Undang-undang Perbankan No. 10 tahun 1998, kredit (yang dpraktekkan di bank konvensional) adalah penyediaan uang atau tagihan yang dapat dipersamakan dengan itu, berdasarkan persetujuan atau kesepakatan pinjam meminjam antara bank dengan pihak lain yang mewajibkan pihak peminjam melunasi utangnya setelah jangka waktu tertentu dengan pemberian bunga.

Secara umum perbedaan antara Bank Syariah dan Bank Konvensional dapat dijelaskan pada tabel berikut :

Tabel 1. Perbedaan Bank Konvensional dan Syariah

\begin{tabular}{|c|c|c|}
\hline Parameter & Bank konvensional & Bank Syariah \\
\hline Landasan hukum & UU Perbankan & UU Perbankan dan Landasan Syariah \\
\hline Return & Bunga, Komisi/fee & $\begin{array}{l}\text { Bagi hasil, margin pendapatan sewa, } \\
\text { komisi/fee }\end{array}$ \\
\hline $\begin{array}{l}\text { Hubungan dengan } \\
\text { Nasabah }\end{array}$ & Debitur-Kreditur & $\begin{array}{l}\text { Kemitraan, investor-investor, Investor - } \\
\text { pengusaha }\end{array}$ \\
\hline $\begin{array}{l}\text { Fungsi dan kegiatan } \\
\text { Bank Mekanisme dan } \\
\text { Objek Usaha }\end{array}$ & $\begin{array}{l}\text { Intermediasi, Jasa } \\
\text { Keuangan }\end{array}$ & $\begin{array}{l}\text { Intermediasi, manager, investasi, } \\
\text { investor, sosial, jasa keuangan }\end{array}$ \\
\hline Prinsip Dasar Operasi & $\begin{array}{l}\text { Tidak anti riba dan } \\
\text { anti maysir }\end{array}$ & Anti riba dan anti maysir \\
\hline Prioritas Pelayanan & $\begin{array}{l}\text { 1. Bebas nilai (prinsip } \\
\text { materialis) } \\
\text { 2. Uang sebagai komoditi } \\
\text { 3. Bunga }\end{array}$ & $\begin{array}{l}\text { 1. Tidak bebas nilai (prinsip syariah } \\
\text { islam) } \\
\text { 2. Uang sebagai alat tukar dan bukan } \\
\text { komoditi } \\
\text { 3. Bagi hasil, jual beli, sewa }\end{array}$ \\
\hline Orientasi & Kepentingan pribadi & Kepentingan publik \\
\hline Bentuk Usaha & Keuntungan & Tujuan sosial-ekonomi Islam, laba \\
\hline Evaluasi Nasabah & Bank komersial & $\begin{array}{l}\text { Bank komersial, bank pembangunan, } \\
\text { bank universal atau multipurpose }\end{array}$ \\
\hline Hubungan Nasabah & $\begin{array}{l}\text { Kepastian pengembalian } \\
\text { pokok dan bunga }\end{array}$ & $\begin{array}{l}\text { Lebih hati-hati karena partisipasi dalam } \\
\text { risiko }\end{array}$ \\
\hline Parameter & Bank Konvensional & Bank Syariah \\
\hline $\begin{array}{l}\text { Sumber Likuiditas } \\
\text { Jangka Pendek }\end{array}$ & Terbatas debitur - kreditur & Erat sebagai mitra usaha \\
\hline Pinjaman Diberikan & Pasar uang, Bank Sentral & Terbatas \\
\hline Prinsip Usaha & $\begin{array}{l}\text { Komersial dan non } \\
\text { komersial, berorientasi laba }\end{array}$ & $\begin{array}{l}\text { Komersial dan nonkomersial, berorien- } \\
\text { tasi laba dan nirlaba }\end{array}$ \\
\hline Pengelolaan dana & Aktiva ke Pasiva & Pasiva ke Aktiva \\
\hline $\begin{array}{l}\text { Lembaga Penyelesai } \\
\text { Sengketa }\end{array}$ & Pengadilan, Arbitrase & $\begin{array}{l}\text { Pengadilan, Badan Arbitrase Syariah } \\
\text { Nasional }\end{array}$ \\
\hline Risiko Investasi & $\begin{array}{l}\text { 1. Risiko bank tidak terkait } \\
\text { langsung dengan debitur, } \\
\text { risiko debitur tidak terkait } \\
\text { langsung dengan bank }\end{array}$ & $\begin{array}{l}\text { 1. Dihadapi bersama antara bank dan } \\
\text { nasabah dengan prinsip keadilan dan } \\
\text { kejujuran } \\
\text { 2. Tidak mungkin terjadi negative spread. }\end{array}$ \\
\hline
\end{tabular}




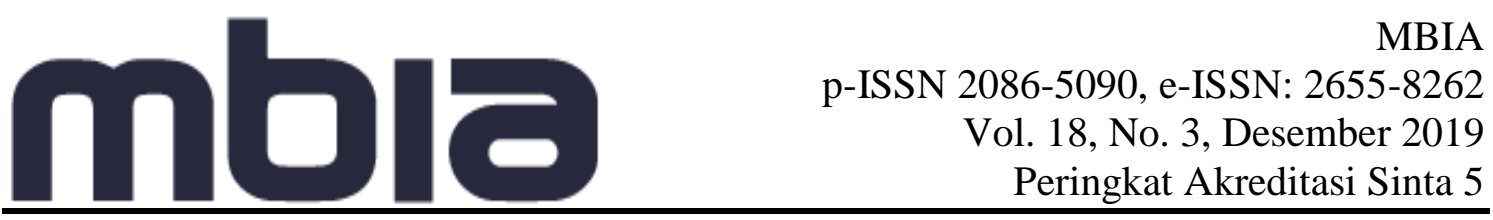

\begin{tabular}{|l|l|l|}
\hline & $\begin{array}{l}\text { 2. Kemungkinan terjadi } \\
\text { negative spread }\end{array}$ & \\
\hline Monitoring Pembiayaan & Terbatas pada Administrasi & $\begin{array}{l}\text { Memungkinkan bank ikut dalam } \\
\text { manajemen nasabah }\end{array}$ \\
\hline $\begin{array}{l}\text { Struktur Organisasi } \\
\text { Pengawas }\end{array}$ & Dewan Komisaris & $\begin{array}{l}\text { Dewan Komisaris, Dewan Pengawas } \\
\text { Syariah, Dewan Syariah Nasional }\end{array}$ \\
\hline Kriteria Pembiayaan & Bankable Halal atau Haram & Bankable Halal \\
\hline Sumber: Rivai dkk. (2007) &
\end{tabular}

\subsection{Kesehatan Bank}

Secara sederhana dapat dikatakan bahwa bank yang sehat adalah bank yang dapat menjalankan fungsi-fungsinya dengan baik. Dengan menjalankan fungsi fungsi tersebut diharapkan dapat memberikan pelayanan yang baik kepada masyarakat serta bermanfaat bagi perekonomian secara keseluruhan. Bank yang tidak sehat, bukan hanya membahayakan dirinya sendiri, akan tetapi pihak lain. Penilaian kesehatan bank sangat penting disebabkan karena bank mengelola dana masyarakat yang dipercayakan kepada bank.

Secara tehnis kesehatan bank adalah kemampuan suatu bank untuk melakukan kegiatan operasional perbankan secara normal dan mampu memenuhi semua kewajibannya dengan baik dengan cara-cara yang sesuai dengan peraturan perbankan yang berlaku (Arif \& Rahmawati, 2015).

Sejak awal sudah disadari bahwa bank harus beroperasi secara sehat karena selain terdapat resiko yang besar, juga mayoritas dana yang dikelola adalah dana masyarakat. Itulah sebabnya Pemerintah melalui Otoritas OJK mengawasi secara ketat dan mengharuskan praktek bisnis yang sehat bagi perbankan di Indonesia. OJK memonitor dan mengawasi kesehatan Bank Umum dari waktu kewaktu terutama sekali dari kinerja keuangannya. Untuk menilai kesehatan Bank Umum OJK menyoroti dari beberapa parameter yaitu aspek permodalan, kualitas assets, manajemen, earning power dan likuiditas yang populer dengan sebutan CAMEL. Belakangan ditambah lagi dengan aspek sensitivitas bisnis. CAMEL tidak sekedar mengukur tingkat kesehatan bank tetapi juga digunakan sebagai indikator dalam menyusun peringkat kinerja bisnis bank.

\subsection{Metode CAMEL}

Bank Indonesia telah melakukan beberapa kali perubahan pada metode penilaian kesehatan bank. Pada 1999, Bank Indonesia menggunakan metode CAMEL yang merupakan singkatan dari Capital, Assets, Management, Earning, dan Liquidity. Setelah diterapkan selama beberapa waktu, metode tersebut dianggap kurang dapat menilai kemampuan bank terhadap risiko eksternal, maka pada 2004 Bank Indonesia melalui Peraturan Bank Indonesia Nomor 6/10/PBI/2004 mengubah metode yang digunakan untuk menilai kesehatan bank menjadi CAMELS. Metode tersebut menambahkan satu elemen lagi yaitu sensitivitas terhadap risiko pasar (Sensitivity to Market Risk). Setelah tujuh tahun peraturan mengenai CAMELS diberlakukan, Bank Indonesia melalui Peraturan Bank Indonesia No.13/1/PBI/2011 menerapkan kebijakan baru mengenai penilaian tingkat kesehatan bank umum. Bank Indonesia mengganti CAMELS Rating System menjadi RiskBased Bank Rating (pendekatan risiko) yang lebih berorientasi pada risiko dan penerapan Good Corporate Governance, yang selanjutnya dikenal dengan metode RGEC. Latar belakang Bank Indonesia mengeluarkan peraturan tersebut adalah karena adanya perubahan kompleksitas usaha dan profil risiko, penerapan pengawasan secara konsolidasi, serta perubahan pendekatan penilaian kondisi bank yang diterapkan secara internasional telah mempengaruhi pendekatan penilaian tingkat kesehatan bank. 
Seharusnya saat ini tolok ukur untuk menilai tingkat kesehatan bank adalah metode RGEC sesuai dengan peraturan OJK yang baru yaitu Surat Edaran OJK nomor 14/SEOJK.03/2017. Namun karena peraturan itu masih relatif baru, baik Laporan Keuangan Bank Syariah Mandiri maupun Bank Mandiri belum menyajikan laporan keuangan yang sesuai dengan peraturan baru tersebut. Maka penelitian ini masih menggunakan metode lama yaitu CAMEL sesuai dengan Surat Edaran Bank Indonesia No.6/23/DPNP tanggal 31 Mei 2004. Rasio CAMEL adalah menggambarkan suatu hubungan atau perbandingan antara suatu jumlah tertentu dengan jumlah yang lain. Dengan analisis rasio dapat diperoleh gambaran baik buruknya keadaan atau posisi keuangan suatu bank. Unsur-unsur penilaian dalam analisis CAMEL adalah sebagai berikut:

\subsection{Capital}

Penilaian atas permodalan bank diukur dengan Capital Adequacy Rasio (CAR), yaitu membandingkan modal terhadap Aktiva Tertimbang Menurut Risiko (ATMR). Ratio ini memperlihatkan seberapa jauh seluruh aktiva bank yang mengandung risiko (kredit, penyertaan, surat berharga, tagihan pada bank lain) ikut dibiayai dari dana modal sendiri. Semakin tinggi CAR menunjukkan semakin besar sumber daya finansial yang dapat digunakan untuk keperluan pengembangan usaha dan mengantisipasi potensi kerugian yang diakibatkan oleh penyaluran kredit (Wardiantika \& Rohmawati, 2014). CAR menunjukkan sejauh mana permodalan suatu bank mampu meminimalisir risiko kegagalan kredit yang mungkin terjadi. Artinya, semakin tinggi CAR menunjukkan bank tersebut semakin sehat dari segi permodalannya. Rumusan rasio adalah sebagai berikut:

$$
C A R=\frac{\text { Modal }}{\text { Aktiva Tertimbang Menurut Risiko }} \times 100 \%
$$

Adapun penilaian rasio Capital Adequacy Ratio (CAR) berdasarkan peraturan Bank Indonesia antara lain :

Tabel 2 : Kriteria Pengukuran Rasio CAR

\begin{tabular}{|c|c|c|}
\hline Kriteria & Peringkat & Nilai \\
\hline $\mathrm{CAR} \geq 12 \%$ & 1 & Sangat Sehat \\
\hline $9 \% \leq \mathrm{CAR}<12 \%$ & 2 & Sehat \\
\hline $8 \% \leq \mathrm{CAR}<9 \%$ & 3 & Cukup Sehat \\
\hline $6 \% \leq \mathrm{CAR}<8 \%$ & 4 & Kurang Sehat \\
\hline CAR $<6 \%$ & 5 & Tidak Sehat \\
\hline \multicolumn{2}{|l}{} \\
Sumber $:$ Kodifikasi Penilaian Tingkat Kesehatan Bank Tahun 2012
\end{tabular}

\subsection{Assets Quality}

Penilaian didasarkan kepada kualitas aktiva yang dimiliki Bank yang diukur dengan Non Performing Loan (NPL) atau pada bank syariah disebut Non Performing Financing (NPF). Selain menggambarkan resiko kredit, ratio NPL juga berpengaruh teradap peroehan laba. Kredit atau pembiayaan yang tidak lancar akan mengakibatkan tertundanya atau bahkan kegagalan pada penerimaan pendapatan yang diharapkan

Bank sangat fokus pada risiko ini, mengingat bisnis utama bank umum adalah penyaluran kredit atau pembiayaan. Resiko ini paling berkontribusi dalam menyebabkan kesehatan bank yang memburuk. Resiko ini dapat mengurangi modal dengan cepat. Indikator yang menunjukan kerugian akibat risiko kredit tercermin dari besarnya NPL/NPF ini. Rasio ini dirumuskan sebagai berikut: 
mbla

$N P L=\frac{\text { Kredit Bermasalah }}{\text { Total } \text { Kredit }} X 100 \%$

Adapun kriteria rasio NPL/NPF) berdasarkan Peraturan Bank Indonesia sebagai berikut :

Tabel 3 : Kriteria Pengukuran Rasio NPL/NPF

\begin{tabular}{|c|c|c|}
\hline Kriteria & Peringkat & Nilai \\
\hline NPL $\leq 2 \%$ & 1 & Sangat Sehat \\
\hline $2 \%<\mathrm{NPL} \leq 5 \%$ & 2 & Sehat \\
\hline $5 \%<\mathrm{NPL} \leq 8 \%$ & 3 & Cukup Sehat \\
\hline $8 \%<\mathrm{NPL} \leq 11 \%$ & 4 & Kurang Sehat \\
\hline $\mathrm{NPL}>11 \%$ & 5 & Tidak Sehat \\
\hline
\end{tabular}

Sumber : Kodifikasi Penilaian Tingkat Kesehatan Bank Tahun 2012

\subsection{Management}

Penilaian didasarkan pada manajemen permodalan, manajemen aktiva, manajemen rentabilitas, manajemen likuiditas dan manajemen umum. Manajemen bank dinilai atas dasar 250 pertanyaan yang diajukan. Kualitas manajemen dapat dilihat dari kualitas manusianya dalam bekerja. Di samping itu, kualitas manajemen juga dilihat dari segi pendidikan dan pengalaman dari karyawanya dalam manangani berbagai kasus-kasus yang terjadi (Kasmir, 2012). Dalam penelitian ini aspek manajemen tidak diteliti mengingat metode analisis data yang diteliti hanya bersifat rasio dan kuantitatif sedangkan aspek manajemen bersifat kualitatif.

\subsection{Earning}

Rentabilitas merupakan kemampuan bank dalam menghasilkan laba dari aktifitas bisnis bank. Laba merupakan hal yang sangat penting, dengan laba yang dihasilkan dari suatu kegiatan bisnis mengindikasikan bahwa kinerja yang telah dilakukan adalah baik dan dapat meneruskan kelangsungan hidup bisnis itu sendiri (Arifin, 2009).

Penilaian didasarkan kepada rentabilitas suatu bank yaitu melihat kemampuan. suatu bank dalam menciptakan laba. Penilaian rentabilitas merupakan penilaian terhadap kondisi dan kemampuan rentabilitas bank untuk mendukung kegiatan operasionalnya dan permodalan. Rentabilitas adalah hasil perolehan dari investasi (penanaman modal) yang dikarenakan yang dikatakan dengan persantase dari besarnya investasi (Rivai, et al, 2007). Penilaian terhadap faktor rentabilitas (Earning) dalam penelitian ini menggunakan empat indikator, yaitu sebagai berikut :

\subsection{Return On Assets (ROA)}

Return On Asset (ROA) merupakan salah satu rasio profitabilitas yang dapat mengukur kemampuan perusahaan dalam menghasilkan laba dari aktivitas yang digunakan. ROA digunakan untuk mengukur efisiensi dan efektifitas perusahaan di dalam menghasilkan keuntungan dengan memanfaatkan aset yang dimilikinya. Menurut Dendawijaya (2009) rasio ini digunakan untuk mengukur kemampuan manajemen bank dalam memperoleh keuntungan (laba) secara keseluruhan. Semakin besar ROA suatu bank, semakin besar pula tingkat keuntungan yang dicapai bank tersebut dan semakin baik pada posisi bank tersebut dari segi penggunaan aset serta menunjukkan kinerja yang semakin baik, karena tingkat pengembalian (return) semakin besar. Dalam rangka mengukur tingkat kesehatan bank, terdapat perbedaan antara perhitungan ROA berdasarkan teoritis dan cara perhitungan berdasarkan ketentuan Bank Indonesia. Secara teoritis, laba yang diperhitungkan adalah laba setelah pajak, sedangkan dalam sistem CAMEL, laba yang diperlukan adalah laba sebelum pajak. Rasio ini dirumuskan sebagai berikut: 
mbla

$R O A=\frac{\text { Laba Sebelum Pajak }}{\text { Rata-RataTotal Aset }} \times 100 \%$

Adapun penilaian rasio ROA berdasarkan Peraturan Bank Indonesia, antara lain:

Tabel 4 : Kriteria Pengukuran Rasio ROA

\begin{tabular}{|c|c|c|}
\hline Kriteria & Peringkat & Nilai \\
\hline ROA $>1,5 \%$ & 1 & Sangat Sehat \\
\hline $1,25 \%<\mathrm{ROA} \leq 1,5 \%$ & 2 & Sehat \\
\hline $0,5 \%<\mathrm{ROA} \leq 1,25 \%$ & 3 & Cukup Sehat \\
\hline $0 \%<\mathrm{ROA} \leq 0,5 \%$ & 4 & Kurang Sehat \\
\hline ROA $\leq 0 \%$ & 5 & Tidak Sehat \\
\hline
\end{tabular}

Sumber : Kodifikasi Penilaian Tingkat Kesehatan Bank Tahun 2012

\subsection{Return On Equity (ROE)}

Return On Equity (ROE) atau pengembalian atas ekuitas merupakan rasio antara laba setelah pajak atau Earning After Tax (EAT) terhadap total modal sendiri yang berasal dari setoran modal pemilik, laba tidak dibagi dan cadangan lain yang dikumpulkan oleh perusahaan. Rasio merupakan rasio untuk mengukur laba bersih setelah pajak dengan modal sendiri. Standar ROE menurut Otoritas Jasa Keuangan (OJK) adalah $12 \%$. yang dirumuskan sebagai berikut:

$$
R O E=\frac{\text { LabaSetelah Pajak }}{\text { Rata-RataTotal Aset }} X 100 \%
$$

Adapun penilaian rasio ROE berdasarkan Peraturan Bank Indonesia, antara lain:

Tabel 5 : Kriteria Pengukuran Rasio ROE

\begin{tabular}{|c|c|c|}
\hline Kriteria & Peringkat & Nilai \\
\hline ROE $>23 \%$ & 1 & Sangat Sehat \\
\hline $18 \%<$ ROE $\leq 23 \%$ & 2 & Sehat \\
\hline $13 \%<$ ROE $\leq 18 \%$ & 3 & Cukup Sehat \\
\hline $8 \%<$ ROE $\leq 13 \%$ & 4 & Kurang Sehat \\
\hline ROE $\leq 8 \%$ & 5 & Tidak Sehat \\
\hline
\end{tabular}

Sumber : Kodifikasi Penilaian Tingkat Kesehatan Bank Tahun 2012

\subsection{Net Interest Margin (NIM)}

Net Interest Margin / Net Operating Margin (NIM/NOM) atau Margin Bunga Bersih adalah salah satu dari rasio rentabilitas dengan perhitungan menggunakan perbandingan antara pendapatan bunga bersih dengan rata-rata aktiva produktif. Biaya bersih diperoleh dari pendapatan biaya yang dikurangi dengan beban bunga. Standar terbaik NIM menurut Otoritas Jasa Keuangan (OJK) adalh $3 \%$. Rasio NIM dihitung dengan rumus sebagai berikut:

$$
\begin{gathered}
\text { NIM }=\frac{\text { Pendapatan Bunga Bersih }}{\text { Rata-Rata Total Aset Produktif }} \times 100 \% \\
\text { Atau } \\
\text { NOM }=\frac{\text { Pendapatan Bagi Hasil }}{\text { Rata-RataTotal Aset Produktif }} \times 100 \%
\end{gathered}
$$




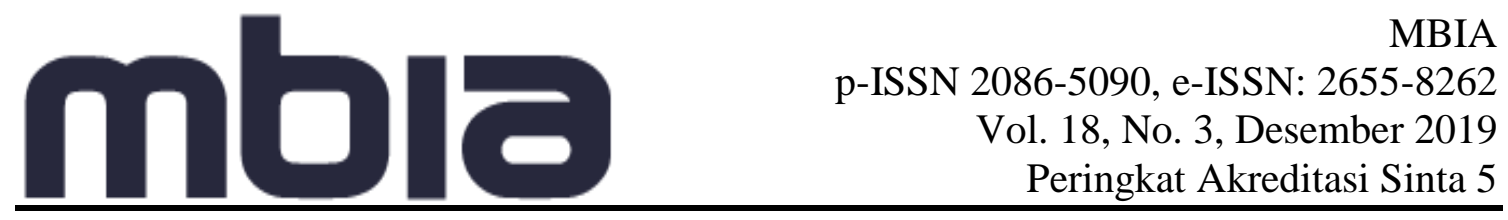

Adapun penilaian rasio NIM/NOM berdasarkan Peraturan Bank Indonesia, antara lain :

Tabel 6 : Kriteria Pengukuran Rasio NIM/NOM

\begin{tabular}{|c|c|c|}
\hline Kriteria & Peringkat & Nilai \\
\hline $\mathrm{NOM}>3 \%$ & 1 & Sangat Sehat \\
\hline $2 \%<\mathrm{NOM} \leq 3 \%$ & 2 & Sehat \\
\hline $1,5 \%<\mathrm{NOM} \leq 2 \%$ & 3 & Cukup Sehat \\
\hline $1 \%<\mathrm{NOM} \leq 1,5 \%$ & 4 & Kurang Sehat \\
\hline $\mathrm{NOM} \leq 1 \%$ & 5 & Tidak Sehat \\
\hline
\end{tabular}

\subsection{Beban Operasional terhadap Pendapatan Operasioanl (BOPO)}

Rasio ini adalah perbandingan antara biaya operasional dengan pendapatan operasional dalam mengukur tingkat efisiensi dan kemampuan bank dalam melakukan kegiatan operasional. Rasio ini menggambarkan efisiensi perbankan dalam melakukan kegiatannya. Biaya operasi merupakan biaya yang dikeluarkan oleh bank dalam rangka menjalankan aktivitas usaha utamanya seperti biaya bunga, biaya pemasaran, biaya tenaga kerja dan biaya operasi lainnya. Sedangkan pendapatan operasi merupakan pendapatan utama bank yaitu pendapatan yang diperoleh dari penempatan dana dalam bentuk kredit dan pendapatan operasi lainnya (Prasnanugraha, 2007). Rasio ini dirumuskan sebagai berikut:

$$
B O P O=\frac{\text { Beban Operasional }}{\text { Pendapatan Operasional }} X 100 \%
$$

Adapun penilaian rasio BOPO berdasarkan Peraturan Bank Indonesia, antara lain:

Tabel 7 : Kriteria Pengukuran Rasio BOPO

\begin{tabular}{|c|c|c|}
\hline Kriteria & Peringkat & Nilai \\
\hline $\mathrm{BOPO} \leq 94 \%$ & 1 & Sangat Sehat \\
\hline $94 \%<\mathrm{BOPO} \leq 95 \%$ & 2 & Sehat \\
\hline $95 \%<\mathrm{BOPO} \leq 96 \%$ & 3 & Cukup Sehat \\
\hline $96 \%<\mathrm{BOPO} \leq 97 \%$ & 4 & Kurang Sehat \\
\hline BOPO $>97 \%$ & 5 & Tidak Sehat \\
\hline
\end{tabular}

\subsection{Liquidity (Faktor Likuiditas)}

Suatu bank yang likuid, apabila bank yang bersangkutan mampu membayar semua utangnya terutama utang-utang jangka pendek antara lain simpanan masyarakat seperti simpanan tabungan, giro, dan deposito. Selain itu bank juga harus dapat pula memenuhi semua permohonan kredit yang layak dibiayai (Kasmir, 2012). Penilaian terhadap faktor likuiditas (Liquidity) dalam penelitian ini menggunakan indikator Loan to Deposito Ratio (LDR) / Financing to Deposit Ratio (FDR). LDR / FDR adalah rasio antara besarnya seluruh volume kredit atau pembiayaan yang disalurkan oleh bank dan jumlah penerimaan dana dari berbagai sumber. Rasio ini juga merupakan indikator kerawanan dan kemampuan dari suatu bank. Rasio ini dirumuskan sebagai berikut:

Atau untuk Bank Syariah

$$
L D R=\frac{\text { Kredit }}{\text { Dana Pihak Ketiga }} X 100 \%
$$

$$
F D R=\frac{\text { Pembiayaan }}{\text { Dana Pihak Ketiga }} X 100 \%
$$




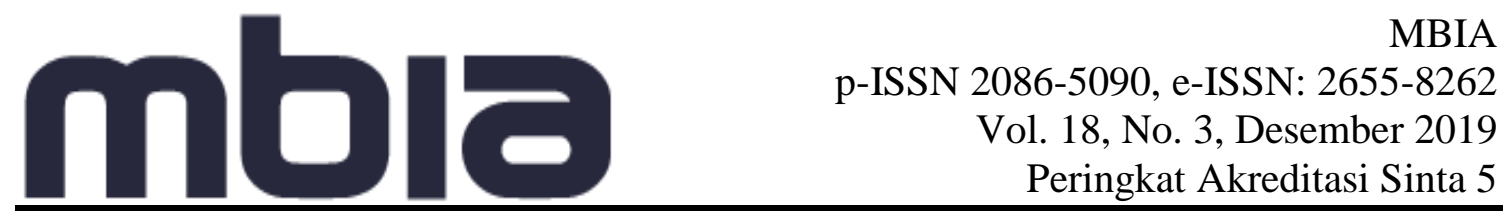

Adapun penilaian rasio LDR/FDR berdasarkan Peraturan Bank Indonesia, antara lain:

Tabel 8 : Kriteria Pengukuran Rasio LDR/FDR

\begin{tabular}{|c|c|c|}
\hline Kriteria & Peringkat & Nilai \\
\hline LDR $\leq 75 \%$ & 1 & Sangat Sehat \\
\hline $75 \%<\mathrm{LDR} \leq 85 \%$ & 2 & Sehat \\
\hline $85 \%<\mathrm{LDR} \leq 100 \%$ & 3 & Cukup Sehat \\
\hline $100 \%<\mathrm{LDR} \leq 120 \%$ & 4 & Kurang Sehat \\
\hline LDR $>120 \%$ & 5 & Tidak Sehat \\
\hline Sumber $:$ Kodifikasi Penilaian Tingkat Kesehatan Bank Tahun 2012
\end{tabular}

Penelitian terdahulu yang mengkaji analisis tingkat kesehatan antara bank syariah dan bank konvensional antara lain Wilson, dkk. (2016) berjudul Analisis Perbandingan Tingkat Kesehatan Perbankan Syariah Dengan Perbankan Konvensional Dengan Metode CAMEL. Hasil penelitian menemukan profitabilitas dan likuiditas perbankan syariah lebih baik dibanding perbankan konvensional. Namun CAR, NPF dan ROA perbankan syariah lebih rendah dari perbankan konvensional. Andreas, dkk (2015) berjudul Analisis Tingkat Kesehatan Bank dengan Metode CAMEL (Studi Perbandingan Pada BRI Tbk \& BTN Tbk Periode 2010-2014). Hasil penelitian menunjukkan terdapat perbedaan yang signifikan kinerja keuangan antara Bank BRI \& Bank BTN Periode 2010-2014. Nindri, dkk. (2017) berjudul Analisis Perbandingan Kinerja Keuangan Bank Mandiri (Persero) Tbk dan Bank Central Asia (Persero). Hasil penelitian menunjukan terdapat perbedaan kinerja keuangan Bank Mandiri dan Bank Central Asia dalam ratio ROA, BOPO dan NPL dan tidak terdapat perbedaan kinerja keuangan dalam CAR, NPM. Riandi, dkk. (2016) berjudul Analisis Kinerja Keuangan PT Bank Syariah Mandiri dan PT Bank Mandiri Tbk dengan Menggunakan Metode CAMEL. Hasil penelitian ini menunjukan tingkat kesehatan masing-masing kedua bank tersebut berada pada kategori Sehat, dengan menggunakan rasio-rasio CAR, NPL, NPM, ROA, BOPO, dan LDR. Sasa, dkk. (2016) berjudul Analisis Perbandingan Kinerja Keuangan Bank Konvensional dan Bank Syariah Berdasarkan Rasio Keuangan Bank. Hasil penelitian ini menunjukkan ada perbedaan bank konvensional dan bank syariah yaitu rasio ROA, BOPO, LDR/FDR, NPL/NPF dan ROE, sedangkan rasio yang sama adalah rasio CAR dan NIM/NOM.

\section{Metodologi Penelitian}

Penelitian dilakukan terhadap BSM dan Bank Mandiri dengan memperbandingkan ratio-ratio keuangan kedua bank. Data ratio keuangan yang diperbandingkan adalah secara horizontal pada laporan keuangan bank-bank ini pada tahun 2014 s/d 2018 yang dipublikasikan. Pembandingan ratio-ratio keuangan ini dengan maksud untuk membandingkan keunggulan dan kelemahan masing-masing untuk seterusnya diberikan analisa manajerial sekaligus alternatif solusi yang rasional berdasarkan kaidah pengelolaan bank yang sehat. Jenis data yang dianalisa adalah data ratio yang bersumber dari laporan keuangan bank yang menjadi objek penelitian ini. Selain itu data juga diperoleh dari literatur buku, majallah, artikel jurnal dan sumber lainnya. Dari uraian diatas dapat dijelaskan bahwa tehnis analisa data pada penelitian ini adalah analisa ratio dan komparatif.

Dalam penelitian ini populasinya adalah Laporan Keuangan BSM dan Bank Mandiri. Sedangkan Sampel ditarik secara Purposive yaitu data laporan keuangan kedua bank yang terbaru (5 tahun terakhir). Sugiyono (2010) mengatakan Purposive Sampling adalah teknik untuk menentukan sampel penelitian dengan pertimbangan tertentu dari peneliti yang bertujuan agar data yang diperoleh lebih representatif. 


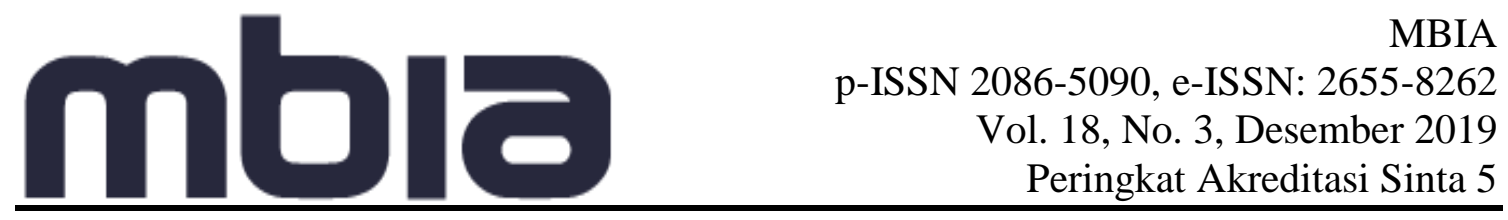

Teknik analisis data dilakukan dengan membandingkan secara langsung terhadap ratio-ratio keuangan kedua bank yang diperbandingkan yaitu Capital Adequacy Ratio (CAR), Non Peforming Loan (NPL), Return On Asset (ROA), Return On Equity (ROE), Net Inters Margin (NIM), Biaya Operasional (BOPO), dan Loan Deposit Ratio (LDR). Untuk mengetahui apakah terdapat perbedaan yang signifikan antara rasio-rasio keuangan kedua bank dilakukan Uji Beda Mann Whitney menggunakan program SPSS versi16.0. Selain itu, untuk melihat tingkat kesehatan pada masing masing ratio, data-data keuangan tersebut dikonfirmasi dengan standar dari OJK.

\section{Hasil dan Pembahasan}

Berdasarkan data laporan kinerja keuangan Bank Syariah Mandiri dan Bank Mandiri data data ratio kedua bank adalah sebagai berikut :

Tabel 9 : Ratio ratio Keuangan BSM dan Bank Mandiri

\begin{tabular}{|l|c|c|c|c|c|c|c|c|c|c|}
\hline \multirow{2}{*}{ Ratio-Ratio } & \multicolumn{7}{|c|}{ Bank Syariah Mandiri (BSM) } & \multicolumn{5}{c|}{ Bank Mandiri } \\
\cline { 2 - 10 } & 2014 & 2015 & 2016 & 2017 & 2018 & 2014 & 2015 & 2016 & 2017 & 2018 \\
\hline & & & & & & & & & & \\
Permodalan/CAR & $14,12 \%$ & $12,85 \%$ & $14,01 \%$ & $15,89 \%$ & $16,26 \%$ & $16,60 \%$ & $18,60 \%$ & $21,36 \%$ & $21,64 \%$ & $20,96 \%$ \\
Kualitas Aset/NPL & $4,29 \%$ & $4,05 \%$ & $3,13 \%$ & $2,71 \%$ & $1,56 \%$ & $0,44 \%$ & $0,60 \%$ & $1,38 \%$ & $1,06 \%$ & $0,67 \%$ \\
Earning Power : & & & & & & & & & & \\
ROA & $-0.04 \%$ & $0,56 \%$ & $0,59 \%$ & $0,59 \%$ & $0,88 \%$ & $3,57 \%$ & $3,15 \%$ & $1,95 \%$ & $2,72 \%$ & $3,17 \%$ \\
ROE & $-3 \%$ & $5,92 \%$ & $5,81 \%$ & $5,72 \%$ & $8,21 \%$ & $25,81 \%$ & $23,03 \%$ & $11,12 \%$ & $14,53 \%$ & $16,23 \%$ \\
NOM/NIM & $6,22 \%$ & $6,54 \%$ & $6,75 \%$ & $7,35 \%$ & $6,56 \%$ & $5,94 \%$ & $5,90 \%$ & $6,29 \%$ & $5,63 \%$ & $5,52 \%$ \\
BOPO & $100,6 \%$ & $94,78 \%$ & $94,12 \%$ & $94,44 \%$ & $90,68 \%$ & $64,98 \%$ & $69,67 \%$ & $80,94 \%$ & $71,78 \%$ & $66,48 \%$ \\
Likuiditas/LDR & $82,13 \%$ & $81,99 \%$ & $79,19 \%$ & $77,66 \%$ & $77,25 \%$ & $82,02 \%$ & $87,05 \%$ & $85,86 \%$ & $87,16 \%$ & $95,46 \%$ \\
\hline
\end{tabular}

Adapun hasil analisis terhadap data data tersebut dikemukakan sebagai berikut :

\section{CAR (Capital Adequacy Ratio)}

Pada tabel diatas terlihat bahwa pada sejak tahun 2014 sampai dengan 2018 CAR pada BSM lebih rendah dari CAR Bank Mandiri. CAR terendah BSM adalah pada tahun 2015 yaitu sebesar 12,85\% dan tertinggi terjadi pada tahun 2018 yaitu sebesar 16,26\%. Sedangkan Bank Mandiri CAR terendah terjadi ditahun 2014 yaitu sebesar 16,60\%. Dan tertinggi sebesar 21,64\% terjadi pada tahun 2017. Meski CAR BSM lebih rendah dari Bank Mandiri namun bila diukur berdasarkan kriteria OJK masih berada pada kategori Sangat Sehat.

\section{NPL (Non Peforming Loan)}

Kondisi NPL BSM sejak tahun 2014 sampai dengan 2017 hanya berada pada posisi Sehat yaitu 4,29\% pada tahun 2014, pada tahun 2015 sebesar 4,05\%, pada tahun 2016 sebesar 3,13\% dan pada tahun 2017 sebesar 2,71\%. Baru pada tahun 2018 naik pada posisi Sangat Sehat. Bila dilihat pada 5 tahun terakhir kualitas portfolio kredit BSM terjadi trend yang terus membaik. Secara keseluruhan kondisi kualitas kredit BSM jauh lebih rendah dari Bank Mandiri dimana sepanjang tahun 2014 sampai dengan 2018 kondisi NPL Bank Mandiri berada pada kondisi Sangat Sehat berdasarkan kriteria OJK. Kondisi NPL Bank Mandiri selama 5 tahun terakhir berturut turut adalah pada tahun 2014 sebesar 0,44\%, pada tahun 2015 sebesar $0,60 \%$, pada tahun 2016 sebesar 1,38\%, pada tahun 2017 sebesar $1,06 \%$, dan pada tahun 2018 sebesar $0,67 \%$. 


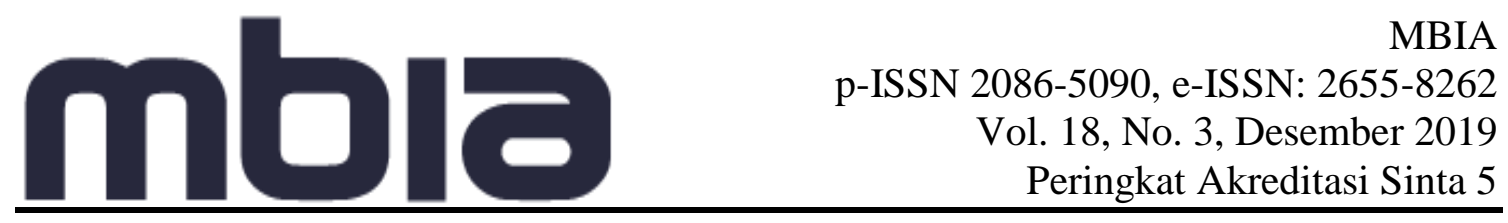

\section{ROA (Return On Asset)}

Profitabilitas BSM dari segi ROA pada 5 tahun terakhir tergolong rendah. Pada tahun 2014 bahkan minus $(-0,04 \%)$ atau tidak sehat berdasarkan kriteria OJS. Baru pada tahun 2015 sampai dengan 2018 masuk kategori cukup sehat level bawah yaitu berkisar pada angka 0,56\% ditahun 2015 dan tertinggi sebesar 0,88\% ditahun 2018. Secara keseluruhan pada 5 tahun terakhir profitabilitas BSM dari aspek ROA jauh dibawah Bank Mandiri. Profitabilitas Bank Mandiri dari aspek ROA tergolong tinggi dan masik kategori Sangat Sehat berdasarkan kriteria OJK. ROA Bank Mandiri pada tahun 2014 mencapai 3,57\%. Dalam 5 tahun terakhir ROA Bank Mandiri paling rendah masih mencapai 1,95\% ditahun 2016 dan angka ini masih masuk kategori Sangat Sehat dalam kriteria OJK.

\section{ROE (Return On Equity)}

Sama halnya dengan ROA, dari aspek ROE juga menunjukkan profitabilitas BSM yang sangat rendah. Bahkan sejak tahun 2014 sampai dengan tahun 2017 kondisi BSM dari segi ROE berada dalam kondisi Tidak Sehat. Baru pada tahun 2018 bisa sedikit naik mencapai Kurang Sehat. Nilai ROE dimaksud adalah -3\% ditahun 2014, sebesar 5,92\% ditahun 2015, pada tahun 2016 sebesar 5,81\%, tahun 2017 sebsar 5,72\% dan pada tahun 2018 sebesar 8,21\%. Hal yang menarik adalah bila dari sisi ROA profitabilitas BSM ditahun 2015 sampai dengan 2018 masuk kategori Cukup Sehat sementara dari aspek ROE berada pada kategori Tidak Sehat dan Kurang Sehat (ditahun 2018). Hal ini diakibatkan pertumbuhan modal lebih lambat dibandingkan pertumbuhan Assets di tahun-tahun tersebut. Bila dibandingkan dengan Bank Mandiri, maka posisi profitabilitas BSM dari aspek ROE jauh lebih rendah. Namun demikian posisi ROE Bank Mandiri hanya di tahun 2014 dan 2015 saja yang masuk kategori Sangat Sehat yaitu masing masing 25,81\% dan 23,03\%. Sejak tahun tahun 2016 sampai dengan 2018 kondisi ROE Bank Mandiri hanya mencapai Cukup Sehat saja.

\section{NIM (Net Interest Margin)}

NOM / NIM pada kedua bank ini menunjukkan kondisi yang tinggi yaitu berada pada tingkat Sangat Sehat berdasarkan kriteria OJK. Semua nilai NOM/NIM berada jauh diatas nilai Sangat Sehat yaitu berkisar 5,90\% sampai dengan 7,35\% sementara masuk kategori sangat sehat kriteria OJK adalah > 3\%. Hal yang menarik adalah nilai NOM/NIM bank BSM elebih tinggi dari NIM Bank Mandiri sementara ROA dan ROE bank BSM jauh lebih rendah. Hal ini disebabkan oleh efisiensi biaya operasional BSM yang sangat rendah yang ditunjukkan oleh nilai BOPO yang tinggi.

\section{BOPO}

Pada tahun 2014 BOP BSM masuk kategori Tidak Sehat yaitu mencapai 100,6\%. Namun sejak tahun 2015 sampai dengan 2017 indikator BOPO bisa mencapai kondisi Sangat Sehat meskipun bila dibandingkan dengan BOPO Bank Mandiri masih jauh lebih besar. Pada tahun 2018 BOPO BSM mampu mencapai angka 90,68 atau masuk kategori Sangat Sehat. Namun bila dibandingkan dengan tingkat BOPO yang dimiliki Bank Mandiri pada tahun yang sama tetap BSM jauh lebih tidak efisien karena BOPO Bank Mandiri hanya sebesar $66,48 \%$. Secara keseluruhan tingkat biaya operasional BSM jauh lebih tinggi dibandingkan dengan Bank Mandiri. Hal ini berimplikasi pada rendahnya profitabilitas BSM dari aspek ROA dan ROE. 


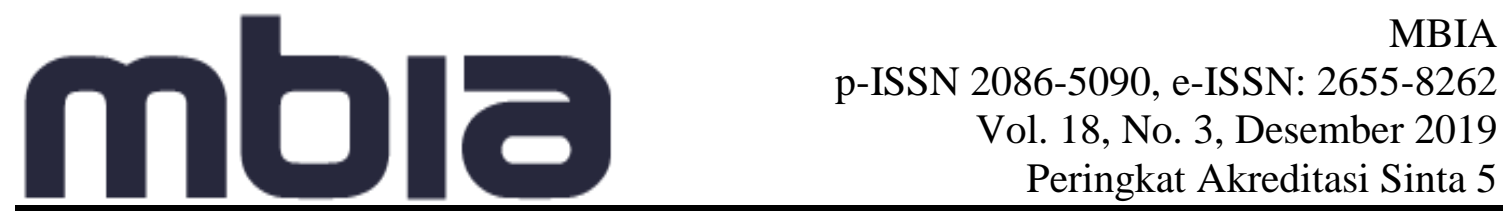

\section{LDR (Loan to Deposit Ratio)}

Dari aspek LDR terlihat bahwa BSM lebih prudent dibandingkan Bank Mandiri yang cenderung ekspansif dalam perkreditan. Bila BSM bertahan pada posisi LDR yang berkisar 77,25\% sampai 88,13\%, maka Bank Mandiri sejak tahun 2015 memiliki LDR berkisar 85,86\% hingga 95,46\% ditahun 2018. Posisi LDR yang rendah pada BSM memang membuat aman dari aspek likuiditas, namun berdampak pada rendahnya profitabilitas. Disisi lain posisi Bank Mandiri yang ekspansif memang mendorong profitabilitas yang tinggi namun rendah dari segi likuiditas. Akan tetapi posisi Bank Mandiri yang demikian moderat didukung oleh kualitas kredit yang baik dan berada pada kondisi Sangat Sehat. Posisi konservatif yang diambil BSM dari aspek LDR juga dipengaruhi oleh kondisi kesehatan kredit (NPL) yang lebih rendah meskipun masih masuk kategori sehat.

\section{Uji Beda Mann Whitney}

Untuk melihat terdapat tingkat perbedaan yang signifikan antara kondisi keuangan BSM dengan Bank Mandiri, dilakukan Uji Beda Mann Whitney dengan bantuan program SPSS versi 16.0 yang hasilnya sebagai berikut :

\section{Tabel 10 : Hasil Uji Beda Mann Whitney}

Test Statistics ${ }^{\mathrm{a}}$

\begin{tabular}{|l|r|}
\hline & RatioKeuangan \\
\hline Mann-Whitney U & 595.000 \\
Wilcoxon W & 1225.000 \\
Z & -1.000 \\
Asymp. Sig. (2-tailed) & .317 \\
\hline a. Grouping Variable : Bank
\end{tabular}

Dari hasil uji beda yang digunakan di atas maka dapat dilihat rasio-rasio keuangan BSM dan Bank Mandiri tidak jauh berbeda atau tidak berbeda secara signifikan. Hal ini terlihat dari hasil uji beda yang jauh lebih besar dari 0,05 yaitu 0,317 . Perbedaan rasio-rasio keuangan dari kedua bank ini hanya bisa diamati secara detail dari perbandingan rasiorasio keuangan secara langsung sebagaimana yang telah disajikan terdahulu.

Ratio kecukupan modal BSM dan Bank Mandiri keduanya berada dalam kategori Sangat Sehat. Meski demikian CAR yang dimiliki Bank Mandiri lebih tinggi dari BSM. Hal ini terjadi karena Bank Mandiri dalam 5 tahun terakhir memiliki kemampuan menghasilkan laba yang lebih tinggi yang berarti dalam menghasilkan sumber dana secara internal lebih tinggi pula. Kemampuan mencetak laba yang lebih tinggi juga disebabkan tingkat efisiensi yang baik dalam biaya operasional yang tentunya juga disebabkan beban dalam menyisihkan PPAP juga lebih kecil karena kualitas kreditnya yang lebih baik. Tantangan bagi BSM dalam meningkatkan permodalan tentunya manajemen harus meningkatkan efisiensi biaya operasional, mencari sumber sumber dana murah dan mengelola aktiva produktif terutama kredit yang harus lebih hati hati sehingga dapat memelihara portfolio kredit yang berkualitas. Karena proses penyelesaian kredit bermasalah yang cenderung lebih lunak pada perbankan syariah, maka komunikasi yang baik dengan nasabah harus 


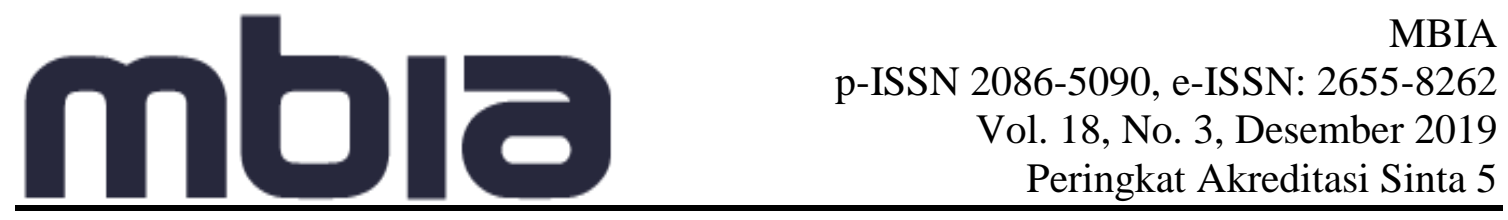

terjalin dengan baik sehingga proses penyelesaian kredit bermasalah juga bisa lebih cepat dan mudah.

Relevan dengan penjelasan diatas, Bank Mandiri memang memiliki kualitas portfolio kredit yang tergolong sangat baik dan masuk kategori Sangat Sehat. Implikasinya jelas akan memiliki kemampuan menghasilkan laba yang baik, biaya operasional khususnya dalam kegiatan penyelesaian kredit bermasalah juga relatif kecil. Selain itu beban dalam membentuk PPAP juga relatif ringan. Lain halnya dengan BSM yang memiliki kulitas kredit yang kurang baik meskipun masih masuk kategori sehat. Namun NPL yang agak tinggi berimplikasi pada peningkatan beban biaya operasional dan kewajiban membentuk PPAP yang lebih tinggi. Perlu penataan manajemen kredit yang lebih baik sehingga kualitas kredit BSM dapat ditingkatkan.

Profitabilitas BSM dari parameter ROA tergolong rendah, jauh dibawah Bank Mandiri. Berdasarkan parameter ROE bahkan BSM jauh lebih rendah lagi. Namun bila dilihat dari aspek NIM kedua bank memiliki tingkat ratio yang relatif sama dan bahkan BSM sedikit lebih baik. Namun NIM yang relatif baik yang dimiliki BSM digembosi oleh biaya operasional yang tinggi sebagaimana diperlihatkan ratio BOPO yang selain tinggi juga jauh lebih tinggi dibandingkan dengan Bank Mandiri. Akibatnya profitabilitas BSM jauh lebih rendah yang berimplikasi pada kemampuan menghasilkan sumber dana internal. Bila hal ini tidak ditangani dengan hati-hati sangat memungkinkan akan mengurangi kepercayaan dan minat nasabah deposan mengingat konsekwensi sistem bagi hasil yang berdampak pada rendahnya return yang akan diterima nasabah yang menyimpan dananya di BSM.

Penyaluran dana dalam bentuk pembiayaan memang BSM lebih prudent dibandingkan Bank Mandiri yang cenderung ekspansif dalam perkreditan. Memang kebijakan yang konservatif dalam penyaluran kredit akan lebih aman dari segi likuiditas namun dari sisi rentabilitas akan sangat rendah. Sangat dimungkinkan kebijakan yang konservatif dari BSM diakibatkan bank ini masih berkutat dengan kredit bermasalah yang memang lebih tinggi. Posisi Bank Mandiri yang ekspansif dibidang kredit memang mendorong profitabilitas yang tinggi namun rendah dari segi likuiditas. Akan tetapi posisi Bank Mandiri yang demikian moderat didukung oleh kualitas kredit yang baik dan berada pada kondisi Sangat Sehat.

\section{Uji Beda Mann Whitney}

Berdasarkan hasil Uji Beda Mann Whitney terlihat nilai Asymp.Sig. (2-tailed) sebesar 0,317 (< 0,05). Nilai signifikansi ini menunjukkan tidak adanya perbedaan yang signifikan antara ratio ratio keuangan BSM dengan Bank Mandiri. Perbedaan perbedaan yang ditunjukkan dengan menelusuri secara langsung ratio ratio keuangan kedua bank sebagaimana dikemukakan sebelumnya, ternyata secara umum masih dinilai perbedaan itu tidak signifikan.

\section{Simpulan}

Berdasarkan hasil analisis data dan pembahasan diatas, maka dapat diambil kesimpulan sebagai berikut: 


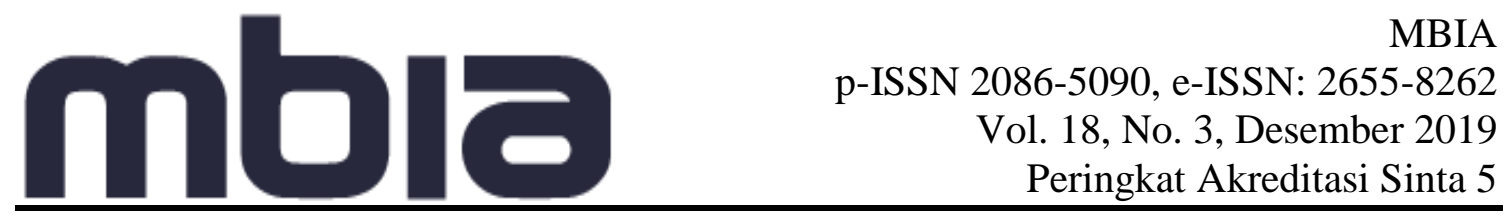

1. CAR terendah BSM masih berada pada predikat sangat baik berdasarkan kriteria OJK. Namun demikian CAR BSM lebih kecil dan lebih lambat tumbuh di bandingkana CAR Bank Mandiri. Hal ini menunjukkan keunggulan Bank Mandiri dalam memupuk sumber dana internal dalam meningkatkan modal.

2. NPL BSM lebih tinggi dari Bank Mandiri. Karakteristik pembiayaan pada bank syariah memang sangat berbeda kredit pada bank konvensional. Bila pada bank konvensional penyelesaian kredit bermasalah langkah-langkahnya lebih praktis dan bisa langsung sita jaminan, maka penyelesaian pembiayaan bermasalah pada bank syariah cenderung lebih lambat karena lebih mengedepankan pendekatan musyawarah.

3. Baik ROA maupun ROE pada Bank Mandiri jauh lebih baik dari BSM. Akan tetapi dari segi NOM/NIM kedua bank relatif sama dan bahkan BSM sedikit lebih baik. Namun karena BOPO pada BSM yang jauh lebih tinggi maka pada akhirnya profitabilitasnya akan semakin rendah. Biaya operasional yang tinggi juga disebabkan NPL yang lebih tinggi.

4. Dari aspek LDR terlihat bahwa BSM lebih prudent dibandingkan Bank Mandiri yang cenderung ekspansif dalam perkreditan. Posisi LDR yang rendah pada BSM memang membuat aman dari aspek likuiditas, namun berdampak pada rendahnya profitabilitas. Disisi lain posisi Bank Mandiri yang ekspansif memang mendorong profitabilitas yang tinggi namun rendah dari segi likuiditas. Akan tetapi posisi Bank Mandiri yang demikian moderat didukung oleh kualitas kredit yang baik dan berada pada kondisi Sangat Sehat. Posisi konservatif yang diambil BSM dari aspek LDR juga dipengaruhi oleh kondisi kesehatan kredit (NPL) yang lebih rendah meskipun masih masuk kategori sehat.

5. Berdasarkan Uji Beda Mann Whitney, tidak terdapat perbedaan yang signifikan secara statistik pada variabel CAR, NPL, ROA, ROE, NIM, BOPO dan LDR antara BSM dan Bank Mandiri.

BSM memiliki kelemahan terutama dari aspek kualitas aktiva produktif dan profitabilitas bila dibandingkan dengan Bank Mandiri. Hal ini bagi BSM berdampak pada meningkatnya biaya operasional dan rendahnya kemampuan meraih laba serta pertumbuhan assets berbasis profit generation (internal) menjadi sangat rendah. Oleh karena itu agar BSM mampu mengejar ketertinggalannya dan mampu berkembang memanfaatkan potensi pasar di Indonesia, bank ini harus membenahi kualitas aktiva produktif terutama kualitas pembiayaan dan sedapat mungkin meningkatkan efisiensi pada biaya operasional guna memperlebar margin laba. Selain itu perlu dikembangkan produk-produk fee based income.

\section{Daftar Pustaka}

Arif. Al. Rianto. Nur. M \& Rahmawati Yuke. (2015). Manajemen Risiko Perbankan Syariah. Jakarta : UIN Syarif Hidayatullah.

Andreas Tunena1, S.L.V.H. Joyce Lapian \& Jantje L. Sepang. (2015). Analisis Tingkat Kesehatan Bank Dengan Metode CAMEL (Studi Perbandingan Pada BRI Tbk \& BTN Tbk Periode 2010-2014). Jurnal EMBA 1349 Vol.3 No.3.

Boy. Loen \& Sonny. Ericson. (2007). Manajemen Aktiva Pasiva Bank Non Devisa, Jakarta: PT Grasindo. 


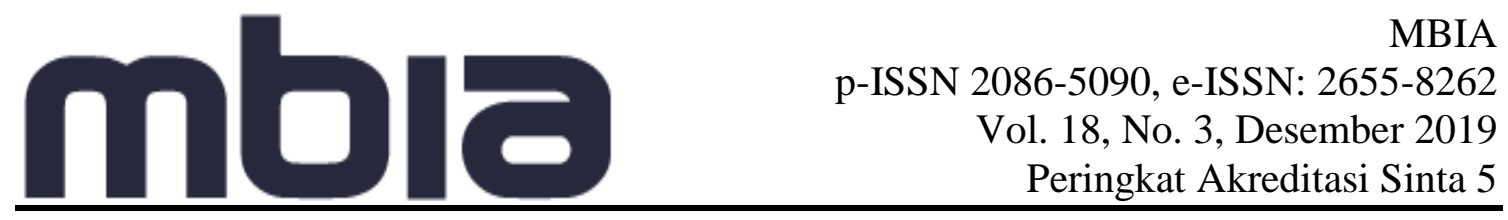

Budisantoso, Totok, \& Triandanu, Sigit. (2011). Bank dan Lembaga Keuangan Lain. Jakarta: Salemba Empat.

Dendawijaya, Lukman. (2009). Manajemen Perbankan. Jakarta: Ghalia Indonesia.

Indriantoro, Nur dan Bambang Supomo. (2002). Metodologi Penelitian Bisnis untuk Akuntansi dan Manajemen edisi pertama. Yogyakarta: BPFE

Institut Bankir Indonesia (1999). Kamus Perbankan Indonesia. jilid 2 edisi kedua, Jakarta.

Kasmir, (2014). Bank dan Lembaga Keuangan Lainya Edisi Revisi 2014. Jakarta : PT Raja Grafindo Persada.

Kasmir, (2012). Manajemen Perbankan edisi refisi. Jakarta : Rajawali Pers.

Mervyn Lewis dan Latifa Algaoud. (2001). Perbankan Syariah Prinsip, Praktik, Prospek. Yakarta : Serambi.

Martono, (2010). Bank dan Lembaga Keuangan Lainya. Yogyakarta : Ekonisia.

Mulyaningrum, Penni. (2008). Pengaruh Rasio Keuangan Terhadap Kebangkrutan Bank di Indonesia, Undip, Semarang.

Nindri Wensen, Sri Murni \& Victoria Untu. (2017). Analisis Perbandingan Kinerja Keuangan Bank Mandiri (Persero) Tbk Dan Bank Central Asia (Persero) Tbk Periode Tahun 2011-2015. Jurnal EMBA Vol.5 No.2.

Nazir, Moh, Ph.D. Metode penelitian. Bogor: Ghalia Indonesia Anggota IKAPI

Prawironegoro, Darsono, Purwanti, Ari \& Utari, Dewi. (2014). Manajemen Keuangan Edisis Revisi. Kajian Praktik dan Teori dalam mengelola Keuangan

Organisasi Perusahaan. Jakarta : Mitra Wacana Media.

Prasnanugraha P, Ponttie, (2007). Analisis Pengaruh Rasio-rasio Keuangan Terhadap Kinerja Bank Umum di Indonesia. UNDIP, Semarang.

Prasetyo. Indra. (2008). Analisis Kinerja Bank Syariah dan Bank Konvensional di Indonesia. Jurnal Aplikasi Manajemen. Volume 6. Nomor 2. Agustus, Surabaya.

Riyadi. Slamet \& Yulianto. Agung. (2014). Pengaruh Pembiayaan Bagi Hasil, Pembiayaan Jual Beli, Financing To Deposit Ratio (FDR) dan Non Performing Financing (NPF) Terhadap Profitabilitas Bank Umum Syariah Di Indonesia, Jurnal Ekonomi, Semarang.

Riandi Chandra, Maryam Mangantar, \& Sem G Oroh. (2016). Analisis Kinerja Keuangan PT Bank Syariah Mandiri Dan PT Bank Mandiri Tbk Dengan Menggunakan Metode CAMEL, Jurnal Berkala Ilmiah Efisiensi Volume 16 Nomor 02

Rifai, Veithzal dan Andria Permata Veithzal. (2008). Islamic Financial Management. Jakarta: PT Raja Grafindo Persada.

Sasa Elida Sovia, Muhammad Saifi \& Achmad Husaini. (2016), Analisis Perbandingan Kinerja Keuangan Bank Konvensional Dan Bank Syariah Berdasarkan Rasio Keuangan Bank (Studi pada Bank Konvensional yang Terdaftar di BEI yang Memiliki Bank Syariah Periode 2012-2014), Jurnal Administrasi Bisnis (JAB) Vol. 37 No. 1

Wardiantika. Lifstin \& Rohmawati. Kusumanigtias. (2004). Pengaruh DPK, CAR, NPF, dan SWBI Terhadap Pembiayaan Murabahah Pada Bank Umum Syariah (Tahun 2008-2012). Jurnal. Fakultas Ekonomi Universitas Negeri Surabaya. 


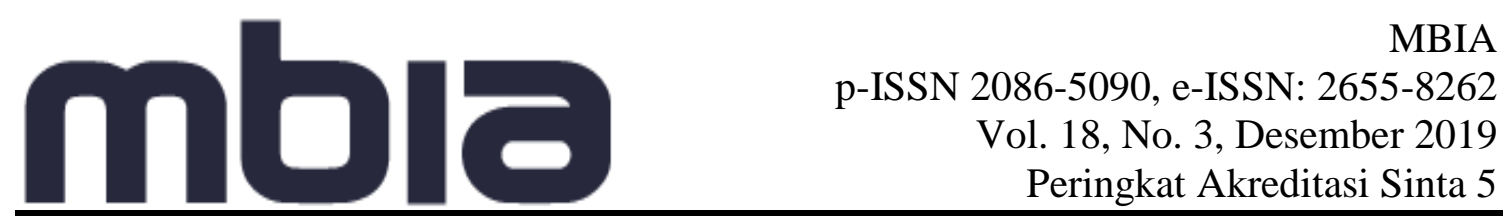

Wilson Lupa, Tommy Parengkuan, \& antje Sepang. (2016). Analisis Perbandingan Tingkat Kesehatan Perbankan Syariah Dengan Perbankan Konvensional Dengan Metode Camel." Jurnal Berkala Ilmiah Efisiensi Volume 16 No. 01.

Yanti \& Susila. (2014). Analisis Tingkat Kesehatan Bank Dengan Menggunakan Metode CAMEL, e-Journal Bisma. Vol.2.

Otoritas Jasa Keuangan. Surat Edaran Otoritas Jasa Keuanga (OJK) N0.14/SEOJK.03/2017 tentang Penilaian Tingkat Kesehatan Bank Umum, Lampiran $1,2,3$

Salinan Surat Edaran Otoritas Jasa Keuangan N0.14/SEOJK.03/2017 tentang Penilaian Tingkat Kesehatan Bank Umum

Salinan Peraturan Otoritas Jasa Keuangan N0.4/POJK.03/2016 tentang Penilaian Tingkat Kesehatan Bank Umum Peraturan Otoritas Jasa Keuangan No.4/ POJK.03/2016 tanggal 26 Januari 2016 tentang Penilaian Tingkat Kesehatan Bank Umum dengan menggunakan pendekatan risiko (Risk - Based Bank Rating)

Bloket Perbankan Indonesia 2015 Otoritas Jasa Keuangan Edisi 2, Mai 2015, ISSN : 1858-4233

Bloket Perbankan Indonesia. 201. Otoritas Jasa Keuangan Edisi 1, Mai 2014, ISSN : 1858-4233

Bank Indonesia. Booklet Perbankan Indonesia. 2014. Edisi 1. Maret 2014. Otoritas Jasa Keuangan.

Peraturan Bank Indonesia Nomor 6/10/PBI/2004 tanggal 12 April 2004 tentang Sistem Penilaian Tingkat Kesehatan Bank Umum (Lembaran Negara Republik Indonesia Tahun 2004 Nomor 38

Surat Edaran Bank Indonesia No.6/23/DPNP/2004 Jakarta, 31 Mai 2004 tentang Sistem Penilaian Tingkat Kesehatan Bank Umum

Peraturan Bank Indonesia No. 13/1/PBI/2011 tentang Penilaian Kesehatan Bank Umum

Surat Edaran Bank Indonesia (SEBI) Nomer. 13/24/DPNP/2011 tentang Penilaian Kesehatan Bank Umum

Surat Edaran Bank Indonesia (SE BI ) No 06/23/DPNP tanggal 31 Mei 2004

Surat Edaran Bank Indonesia (SE BI) Nomor 13/3/DPNP Tanggal 16 Desember 2011

Surat Edaran No.9/24/DPBS tanggal 30 Oktober 2007 PBI No.9/1/PBI/2007

tanggal 24 Januari 2007 penilaian kesehatan bank berdasarkan prinsip syariah

Kodifikasi Penilaian Tingkat Kesehatan Bank Tahun 2012.

\section{Copyright Disclaimer}

Copyright for this article is retained by the author(s), with first publication rights granted to the journal. 